\title{
Research Paper Growth rate of wheat crop in Basti Division of Eastern Uttar Pradesh, India
}

\author{
Neeraj Singh and Piyush Kumar Singh
}

See end of the paper for authors' affiliations

Correspondence to :

\section{Neeraj Singh}

Department of Agricultural

Statistics, Narendra Dev

University of Agriculture and Technology,

Kumarganj, Faizabad

(U.P.) India

Email : neeraj.agristat@ gmail.com

\section{Paper History :}

Received : 30.01.2019;

Revised : 04.02.2019;

Accepted : 14.02.2019
ABSTRACT : The present paper attempts to analyze the growth rate for area, production and productivity of wheat crop in Basti Division of Eastern Uttar Pradesh. The time series data on area, production and productivity of wheat crop pertaining from "Sankhyakiya Patrika" to the period 200001 to 2014-15 were used for the study. The per cent change was estimated on the basis of triennium average for area, production and productivity which is increased substantially with 7.79, 34.13 and 24.44 per cent, respectively. Graphical presentations have shown the trends in area, production and productivity of wheat. The growth rate was examined by compound annual growth rate (CAGR) which is 0.59 per cent for area, 2.56 per cent for production and for its productivity 1.96 per cent. Decomposition analysis shows the dominant effect of productivity for the growth in wheat production.

KEY WORDS : Wheat, Basti, Trends, CAGR, Instability index, Decomposition analysis

How To Cite This PAPer : Singh, Neeraj and Singh, Piyush Kumar (2019). Growth rate of wheat crop in Basti Division of Eastern Uttar Pradesh, India. Internat. Res. J. Agric. Eco. \& Stat., 10 (1) : 96-100, DOI : 10.15740/ HAS/IRJAES/10.1/96-100. Copyright@ 2019: Hind Agri-Horticultural Society. 